\title{
Fc receptors: Cell activators of antibody functions
}

\author{
Carlos Rosales $^{1 *}$, Eileen Uribe-Querol ${ }^{2}$ \\ ${ }^{1}$ Immunology Department, Instituto de Investigaciones Biomédicas, Universidad Nacional Autónoma de México, Mexico City, \\ Mexico \\ ${ }^{2}$ División de Estudios de Posgrado e Investigación, Facultad de Odontología, Universidad Nacional Autónoma de México, Mexico \\ City, Mexico \\ Email: *arosal@unam.mx
}

Received January $18^{\text {th }}, 2013$; revised March $12^{\text {th }}, 2013$; accepted April $16^{\text {th }}, 2013$

Copyright (C) 2013 Carlos Rosales, Eileen Uribe-Querol. This is an open access article distributed under the Creative Commons Attribution License, which permits unrestricted use, distribution, and reproduction in any medium, provided the original work is properly cited.

\section{ABSTRACT}

At the onset of an infection early defense systems, such as complement, get into action. Specialized leukocytes (white blood cells) of the innate immune system, including monocytes, macrophages, and neutrophils also participate as a first line of defense against infections. These early responses are rapid but not very specific and are usually not enough to clear completely many infections. The adaptive immune system is also needed to finish the job against many microorganisms. Antibody molecules, produced during the adaptive immune response, are crucial for preventing recurrent infections. Although, IgG antibodies are essential for controlling infections, these molecules do not directly damage the microorganisms they recognize. Today, it is established that leukocytes of the innate immune system are responsible for the protective effects of these antibodies. IgG molecules bind to their cognate antigens and are in turn recognized by specific receptors (Fc $\gamma$ receptors) on the membrane of leukocytes. Crosslinking these receptors on the surface of leukocytes leads to activation of several effector cell functions. These effector functions are geared toward the destruction of microbial pathogens and the induction of an inflammatory state that is beneficial during infections. However, in autoimmune diseases, antibodies can direct these effector functions against normal tissues and cause severe tissue damage. In recent years, several factors that can modulate the IgG-Fc $\gamma R$ interaction have been elucidated. In this review, we describe the main types of $F c y$ receptors, and our current view of how antibody variants interact with these receptors to initiate different cell responses. In addition, new findings on the signaling role of individual $F c \gamma$ receptors are also discussed.

${ }^{*}$ Corresponding author.
Keywords: Immunoglobulin; Antibody; Immunoreceptor; Neutrophil; Macrophage

\section{INTRODUCTION}

At the onset of an infection by different types of microorganisms, including viruses, bacteria, fungi, and protozoa, early defense systems, such as constitutive expression of antimicrobial peptides, and activation of complement get into action. These systems are rapid but not particularly specific. Specialized leukocytes (white blood cells) of the innate immune system, including monocytes, macrophages, and neutrophils also participate as a first line of defense against infections. These leukocytes can bind some microbial molecules, termed danger- and pathogen-associated molecular patterns (DAMPs and PAMPs, respectively) via numerous receptors such as the Toll-like receptor family [1,2]. In this way, leukocytes recognize microorganisms directly and prevent a massive infection [3]. These early responses however, are usually not enough to clear completely many infections. The adaptive immune system is also needed to finish the job against many microorganisms. Antibody molecules, produced during the adaptive immune response, are crucial for preventing recurrent infections [4]. At the beginning of the adaptive response, antibodies belong to the IgM class. These antibodies present low affinity for microbial antigens, but they can easily activate the classical complement pathway. Complement deposited on microorganisms can induce phagocytosis via complement receptors $[5,6]$, or it can induce bacterial lysis via the formation of the membrane attack complex [7]. At later times of the adaptive response, antibodies belong mainly to the IgG class. These antibodies are of higher affinity and of much greater specificity for their particular antigen. Thus, IgG antibodies are key for controlling many microorganisms, as demonstrated by immunodeficiency disorders, 
with low production of this class of antibodies, in which there is increased susceptibility to microbial infections [4]. Although, IgG antibodies are essential for controlling infections, these molecules do not directly damage the microorganisms they recognize. Today, it is established that leukocytes of the innate immune system are responsible for the protective effects of these antibodies. IgG molecules bind to their cognate antigens via their two fragment antigen-binding (Fab) sites, and are in turn recognized by specific receptors on the membrane of leukocytes. These receptors bind the Fc (fragment crystallizable) domain of IgG; thus, they are named Fcy receptors $(\mathrm{Fc} \gamma \mathrm{R})[8,9]$. In this way, IgG antibodies are the bridge between the two arms of the immune system, bringing together the specificity of recognition of the adaptive immune system and the destructive potential of the cells of the innate immune system. Crosslinking these receptors on the surface of leukocytes leads to activation of several effector cell functions. Depending on the cell type, and also on the Fc $\gamma$ receptor type, these functions include phagocytosis, cell degranulation, production of various cytokines and chemokines, antibody-dependent cell-mediated cytotoxicity (ADCC), and activation of genes [10]. These effector functions are geared toward the destruction of microbial pathogens and the induction of an inflammatory state that is beneficial during infections. However, in autoimmune diseases, antibodies can direct these effector functions against normal tissues and cause severe tissue damage $[11,12]$. It is then of great interest to understand how various $\mathrm{Fc} \gamma \mathrm{R}$ are activated to induce these cellular functions. In recent years, several factors that can modulate the IgG-Fc $\gamma \mathrm{R}$ interaction have been described. These factors include, the particular IgG subclass [13] and the glycosylation pattern of the antibody [14]. In addition, other molecules, such as members of the pentraxin family can bind $\mathrm{Fc} \gamma \mathrm{R}[15,16]$, and certain glycosylation variants of antibodies can bind other cell membrane receptors different from Fc $\gamma \mathrm{R}$ [17-19]. In this review, we describe the main types of $\mathrm{F} c \gamma$ receptors, and our current view of how antibody variants interact with these receptors to initiate different cell responses. In addition, new findings on the signaling role of individual Fc $\gamma$ receptors are also discussed.

\section{Fc $\gamma$ RECEPTORS}

\subsection{Structure}

Antibodies represent an important bridge between the specificity of the adaptive immune system, and the highly destructive mechanisms of cells of the innate immune system. Antibodies bind to microorganisms via their antigen-binding sites, and to $\mathrm{Fc}$ receptors on the surface of leukocytes, via their carboxyl terminal Fc portion. Receptors for the Fc portion of various immunoglobulin (Ig) classes have been described [20]. Fc Receptors for IgG $(\mathrm{Fc} \gamma \mathrm{R})$, for $\operatorname{IgE}(\mathrm{Fc} \varepsilon \mathrm{R})$, and for $\operatorname{IgA}(\mathrm{Fc} \alpha \mathrm{R})$ are known [20]. Crosslinking of Fcy receptors with their IgG antibody ligands triggers various functions in many cells of the immune system. These cell functions include phagocytosis, cell degranulation, production of various cytokines and chemokines, ADCC, and activation of genes $[10,21]$.

$\mathrm{Fc} \gamma$ receptors are a family of glycoproteins, part of the $\operatorname{IgG}$ superfamily. They consist of an IgG binding $\alpha$-subunit, that usually pairs with accessory $\gamma$ chains, which are important for receptor signaling (Figure 1).

In humans, three classes of $\mathrm{Fc} \gamma \mathrm{R}$ have been identified, Fc $\gamma$ RI (CD64), Fc $\gamma$ RII (CD32), and Fc $\gamma$ RIII (CD16) (Figure 1A) [22]. Fc $\gamma \mathrm{R}$ are coded for by different genes and differ in their relative avidity for IgG, molecular structure, and cellular distribution. Fc $\gamma \mathrm{RI} \alpha$-subunit presents three Ig-like extracellular domains, and binds monomeric IgG [23]. In contrast, Fc $\gamma$ RII and Fc $\gamma$ RIII present two Ig-like extracellular domains, and bind only multimeric immune complexes. Fc $\gamma$ RI, expressed on monocytes, macrophages, and interferon- $\gamma($ IFN- $\gamma)$-stimulated neu-

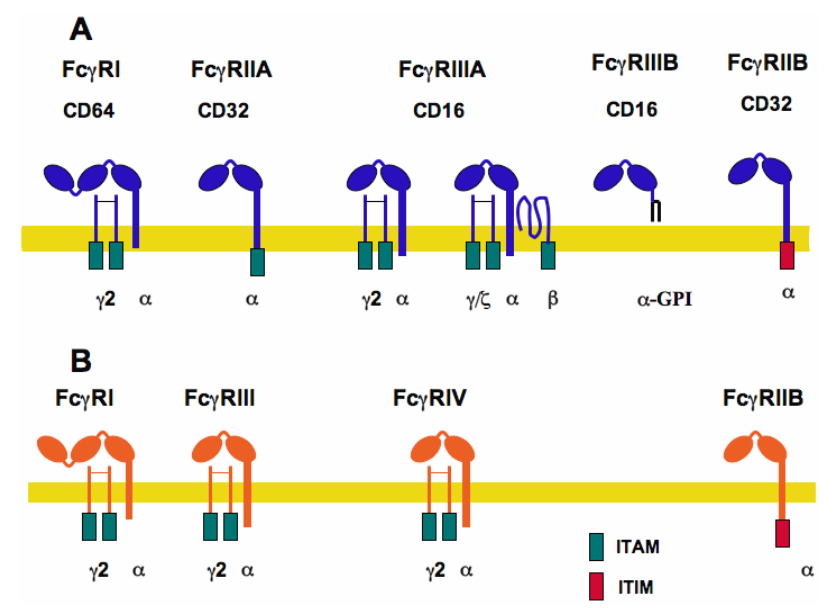

Figure 1. Fc $\gamma$ Receptor family. (A) The human family of receptors for the Fc portion of immunoglobulin G (IgG) molecules comprises three members Fc $\gamma$ RI, Fc $\gamma$ RII, and Fc $\gamma$ RIII. The IgG binding $\alpha$-subunit in the high affinity Fc $\gamma \mathrm{RI}$, possesses three immunoglobulin (Ig)-like extracellular domains. The $\alpha$ subunit in the other low-affinity receptors presents only two Ig-like domains. Activating receptors contain an ITAM (immunoreceptor tyrosine-based activation motif) sequence within the $\alpha$ subunit (for Fc $\gamma$ RIIA) or within the accessory $\gamma$ and $\zeta$ chains. In contrast, Fc $\gamma$ RIIB is an inhibitory receptor containing an ITIM (immunoreceptor tyrosine-based inhibition motif) sequence. Fc $\gamma$ RIIIB is also an activating receptor, which is bound to the cell membrane via a glycosylphosphatidylinositol (GPI) anchor; (B) The murine family of receptors for the Fc portion of immunoglobulin $\mathrm{G}$ molecules comprises four members Fc $\gamma$ RI, Fc $\gamma$ RIIB, Fc $\gamma$ RIII, and Fc $\gamma$ RIV. Activating receptors (Fc $\gamma$ RI, Fc $\gamma$ RIII, and Fc $\gamma$ RIV) contain an ITAM sequence within the accessory $\gamma$ chains; while the inhibitory receptor ( $\mathrm{Fc} \gamma \mathrm{RIIB})$ contains an ITIM sequence. 
trophils, is associated with a dimer of the common Fc receptor (FcR) gamma-chain (also named $\mathrm{FcR} \gamma$ chain). Each $\gamma$ chain contains tyrosine residues that are phosphorylated upon receptor activation and become docking sites for other signaling molecules. These tyrosine residues are found within a common motif known as ITAM, for immunoreceptor tyrosine-based activation motif [24, 25]. There are several isoforms of Fc $\gamma$ RII, derived from its three genes and from alternative splicing. Fc $\gamma$ RII isoforms are distributed differently on hematopoietic cells. Fc $\gamma$ RIIA and Fc $\gamma$ RIIC are found mainly in phagocytic cells (neutrophils, monocytes, and macrophages), whereas Fc $\gamma$ RIIB is expressed mainly in B lymphocytes [22]. Fc $\gamma$ RIIB expression is inducible in phagocytic leukocytes, for the negative regulation of cell functions, such as phagocytosis $[8,26]$. The human Fc $\gamma$ RIIA is a particular receptor that does not have associated FcR $\gamma$ chains. Fc $\gamma$ RIIA contains an ITAM in its cytoplasmic portion, while Fc $\gamma$ RIIB has a different tyrosine-containing motif involved in negative signaling. This motif is known as ITIM, for immunoreceptor tyrosine-based inhibition motif [27]. Fc $\gamma$ RIII has two isoforms: Fc $\gamma$ RIIIA is a receptor with a transmembrane portion and a cytoplasmic tail, associated with an ITAM-containing homodimer of FcR $\gamma$ chains on macrophages, natural killer (NK) cells, and dendritic cells. Fc $\gamma$ RIIIA expressed on basophils and mast cells associates with a heterodimer of $\gamma / \zeta$ chains and an extra $\beta$ chain (Figure 1A) [22,23]. Fc $\gamma$ RIIIB is present exclusively on neutrophils and it is a glycosylphosphatidylinositol (GPI)-linked receptor, lacking a cytoplasmic tail. No other subunits are known to associate with it, and its signaling mechanism remains unidentified (Figure 1A). It is also worth noting that human Fc $\gamma$ RIIA and Fc $\gamma$ RIIIB are exclusive receptors that are not found in other species [28].

In mice, several $\mathrm{Fc} \gamma$ receptors have also been described (Figure 1B). These receptors are very similar, yet not identical, to the human Fc $\gamma \mathrm{R}$ [8]. Fc $\gamma \mathrm{RI}$ is expressed on monocytes and macrophages, and it is also associated with a dimer of FcR $\gamma$ chains, which contain the ITAM motifs involved in receptor signaling. Fc $\gamma$ RIII is a receptor with a transmembrane portion and a cytoplasmic tail, associated with a dimer of $\mathrm{FcR} \gamma$ chains, containing ITAMs. This receptor is closer to the human Fc $\gamma$ RIIA, as revealed by the genetic structure of FcRs in various species [13]. Fc $\gamma \mathrm{RIV}$ is also an activating receptor expressed together with a dimer of FcR $\gamma$ chains [29], and it is closer to the human Fc $\gamma$ RIIIA (Figure 1B). Fc $\gamma$ RIV may be the most relevant activating $\mathrm{Fc} \gamma \mathrm{R}$ in mice, due to its ability to bind IgG2a and IgG2b with higher affinity [13]. Fc $\gamma$ RIIB is the negative receptor containing an ITIM motif in its cytoplasmic tail. It is expressed mainly in B lymphocytes but also in phagocytic leukocytes and dendritic cells. Fc $\gamma$ RIIB, described first in B lymphocytes, down regulates the activation signals from the $\mathrm{B}$ cell antigen receptor (BCR) to inhibit antibody production by the $\mathrm{B}$ cell [30]. This inhibitory receptor also helps to regulate initiation of other cell functions in phagocytic leukocytes and dendritic cells by creating, together with activating Fc $\gamma$ receptors, a threshold for cell activation $[13,31]$.

\subsection{Cell Expression of Fc $\gamma$ Receptors}

Fc $\gamma$ receptors are found on many cells of the immune system, including granulocytes such as neutrophils and eosinophils; phagocytes such as neutrophils, monocytes and macrophages; and lymphocytes such as natural killer cells and B cells [23]. The wide variety of cellular responses regulated by $\mathrm{Fc} \gamma$ receptors is consequently not surprising. Monocytes and macrophages express all types of activating Fc $\gamma$ receptors, Fc $\gamma$ RI, Fc $\gamma$ RII, and Fc $\gamma$ RIII in humans, and Fc $\gamma$ RI, Fc $\gamma$ RIII, and Fc $\gamma$ RIV in mice (Table 1). Murine neutrophils express Fc $\gamma$ RIII, and Fc $\gamma$ RIV, whereas human neutrophils express Fc $\gamma$ RIIA and Fc $\gamma$ RIIIB. It is noteworthy to mention that human neutrophils have the two unique $\mathrm{Fc} \gamma \mathrm{R}$, not present in neutrophils of other species. Thus, care should be taken when analyzing data derived from mouse studies of neutrophil Fc $\gamma \mathrm{R}$ function, since conclusions may not necessarily apply to human neutrophils. NK cells exclusively express Fc $\gamma$ RIIIA in humans and Fc $\gamma$ RIII in mice. Dendritic cells (DCs) also express various Fc $\gamma \mathrm{Rs}$, while B lymphocytes express mainly the inhibitory Fc $\gamma$ RIIB (Table 1). Some T lymphocyte populations have also been reported to express Fc $\gamma$ Rs [32-34], but the role for these receptors in $\mathrm{T}$ cell function or development remains unclear and requires further studies.

\subsection{Fc $\gamma$ Receptor Signaling}

Crosslinking of activating $\mathrm{Fc} \gamma$ receptors with their $\mathrm{IgG}$ antibody ligands triggers various functions in many cells of the immune system. As mentioned before, all activateing receptors contain ITAM motifs involved in receptor signaling. The exact activation mechanism is not completely clear, but at the initial molecular events involve activation of Src family kinases followed by activation of Syk (spleen tyrosine kinase) family kinases.

The model for the initial steps of activating Fc $\gamma \mathrm{R}$ signaling is as follows: Upon crosslinking, the receptor associates with lipid rafts. Lipid rafts are small regions of the plasma membrane that are enriched in cholesterol and sphingolipids [35]. There, the receptor co-localizes with Src kinases. These kinases phosphorylate tyrosines within the ITAM. Phosphorylated tyrosines then become docking sites for Syk. This kinase then phosphorylates multiple substrates, including phosphatidylinositol 3kinase (PI 3-K), phospholipase $\mathrm{C} \gamma(\mathrm{PLC} \gamma)$, and the adap- 
Table 1. Fc gamma receptors.

\begin{tabular}{|c|c|c|c|}
\hline Human & & & \\
\hline Receptor & Principal antibody ligand & Affinity for ligand $^{\mathrm{a}}$ & Cell distribution \\
\hline $\mathrm{Fc} \gamma \mathrm{RI}(\mathrm{CD} 64)$ & $\operatorname{IgG} 1$ and $\operatorname{IgG} 3>\operatorname{IgG} 4>\operatorname{IgG} 2$ & $\begin{array}{c}\text { High } \\
\left(\mathrm{Kd} \sim 10^{8} \mathrm{M}^{-1}\right)\end{array}$ & $\begin{array}{c}\text { Macrophages Neutrophils } \\
\text { Eosinophils } \\
\text { Dendritic cells }\end{array}$ \\
\hline Fc $\gamma$ RIIA (CD32) & $\operatorname{IgG} 1>\operatorname{IgG} 2$ and $\operatorname{IgG} 3>\operatorname{IgG} 4$ & $\begin{array}{c}\text { Low } \\
\left(\mathrm{Kd} \sim 2 \times 10^{6} \mathrm{M}^{-1}\right)\end{array}$ & $\begin{array}{c}\text { Macrophages Neutrophils } \\
\text { Mast cells } \\
\text { Eosinophils } \\
\text { Platelets } \\
\text { Dendritic cells }\end{array}$ \\
\hline Fc $\gamma$ RIIB (CD32) & $\mathrm{IgG} 1>\mathrm{IgG} 2$ and $\mathrm{IgG} 3>\mathrm{IgG} 4$ & $\begin{array}{c}\text { Low } \\
\left(\mathrm{Kd} \sim 2 \times 10^{6} \mathrm{M}^{-1}\right)\end{array}$ & $\begin{array}{c}\text { Macrophages Neutrophils } \\
\text { Mast cells } \\
\text { Eosinophils } \\
\text { Dendritic cells } \\
\text { B Cells }\end{array}$ \\
\hline Fc $\gamma$ RIIIA (CD16A) & $\operatorname{IgG} 1$ and $\operatorname{IgG} 3$ & $\begin{array}{c}\text { Low } \\
\left(\mathrm{Kd} \sim 5 \times 10^{5} \mathrm{M}^{-1}\right)\end{array}$ & $\begin{array}{l}\text { Macrophages } \\
\text { Mast cells } \\
\text { Basophils } \\
\text { NK cells } \\
\text { Dendritic cells }\end{array}$ \\
\hline Fc $\gamma$ RIIIB (CD16B) & IgG and $\operatorname{IgG} 3$ & $\begin{array}{c}\text { Low } \\
\left(\mathrm{Kd} \sim 2 \times 10^{5} \mathrm{M}^{-1}\right)\end{array}$ & Neutrophils \\
\hline \multicolumn{4}{|l|}{ Mouse } \\
\hline Receptor & Principal antibody ligand & Affinity for ligand $^{\mathrm{b}}$ & Cell distribution \\
\hline $\mathrm{Fc} \gamma \mathrm{RI}$ & $\operatorname{IgG} 2 \mathrm{a}$ & $\underset{\mathrm{Kd} \sim 1.6 \times 10^{8} \mathrm{M}^{-1}}{\text { High }}$ & $\begin{array}{c}\text { Monocytes } \\
\text { Macrophages } \\
\text { Dendritic cells }\end{array}$ \\
\hline Fc $\gamma$ RIIB & $\begin{array}{l}\mathrm{IgG1} \\
\mathrm{IgG} 2 \mathrm{a} \\
\mathrm{IgG} 2 \mathrm{~b}\end{array}$ & $\begin{array}{c}\text { Low } \\
\mathrm{Kd} \sim 3.3 \times 10^{6} \mathrm{M}^{-1} \\
\mathrm{Kd} \sim 0.4 \times 10^{6} \mathrm{M}^{-1} \\
\mathrm{Kd} \sim 2.2 \times 10^{6} \mathrm{M}^{-1}\end{array}$ & $\begin{array}{c}\text { B Cells } \\
\text { Dendritic cells }\end{array}$ \\
\hline $\mathrm{Fc} \gamma \mathrm{RIII}$ & $\begin{array}{l}\text { IgG1 } \\
\text { IgG2a } \\
\text { IgG2b }\end{array}$ & $\begin{array}{c}\text { Low } \\
\mathrm{Kd} \sim 0.3 \times 10^{6} \mathrm{M}^{-1} \\
\mathrm{Kd} \sim 0.7 \times 10^{6} \mathrm{M}^{-1} \\
\mathrm{Kd} \sim 0.6 \times 10^{6} \mathrm{M}^{-1}\end{array}$ & $\begin{array}{c}\text { Monocytes } \\
\text { Macrophages Neutrophils } \\
\text { NK cells } \\
\text { Dendritic cells }\end{array}$ \\
\hline Fc $\gamma$ RIV & $\begin{array}{l}\operatorname{IgG} 2 \mathrm{a} \\
\mathrm{IgG} 2 \mathrm{~b}\end{array}$ & $\begin{array}{c}\text { Low } \\
\mathrm{Kd} \sim 2.9 \times 10^{7} \mathrm{M}^{-1} \\
\mathrm{Kd} \sim 1.7 \times 10^{7} \mathrm{M}^{-1}\end{array}$ & $\begin{array}{l}\text { Monocytes } \\
\text { Macrophages } \\
\text { Neutrophils } \\
\text { Dendritic cells }\end{array}$ \\
\hline
\end{tabular}

${ }^{\mathrm{a}}$ Data from $[64,65] ;{ }^{\mathbf{b}}$ Data from $[29,61]$.

or molecules SLP76 (SH2-domain-containing leukocyte protein of $76 \mathrm{kDa}$ ) and LAT (linker for activation of T cells) [36] (Figure 2). These molecules organize and activate several signaling pathways, depending on the cell type, leading to particular cellular responses and to transcriptional changes (Figure 2). For example, SLP76 seems to be important for Fc $\gamma \mathrm{R}$ signaling in neutrophils [37], while it seems to be dispensable in macrophages and NK cells [38,39]. LAT is another adaptor that seems to participate in many $\mathrm{Fc} \gamma \mathrm{R}$-mediated functions (Figure 2). LAT was reported to be constitutively associated with the common FcR $\gamma$ chain in monocytes [40], and to be important for efficient phagocytosis in macrophages [40]. Clearly, further studies are needed to identify the particular adaptor used by each type of Fc receptor in the various leukocytes, and to connect this to a unique cell response.

The inhibitory Fc $\gamma$ RIIB is the negative receptor containing an ITIM motif in its cytoplasmic tail instead of an ITAM sequence [41]. It was described first in B lymphocytes, where it down regulates the activation signals from the B cell antigen receptor (BCR) (Figure 3A) to inhibit antibody production by the B cell [30]. Contrary to the activating receptors that engage several kinases, this inhibitory receptor signals by activation of phosphatases. Inositol 5-phosphatase (SHIP1) is the main enzyme activated upon crosslinking of Fc $\gamma$ RIIB and BCR (Figure 3B) [27]. This phosphatase binds via its SH2 domain, to the phosphorylated tyrosines within the ITIM sequence of Fc $\gamma$ RIIB. SHIP1 transforms phosphatidylinositol-3,4,5-triphosphate $\left(\mathrm{PIP}_{3}\right)$ the main product of $\mathrm{PI}$ $3-\mathrm{K}$, into phosphatidylinositol-3,4-biphosphate $\left(\mathrm{PIP}_{2}\right)$; pre- 


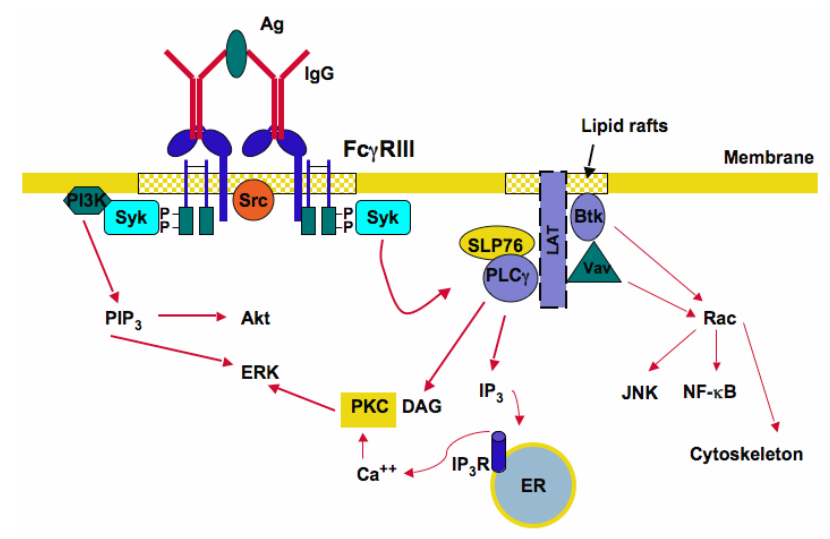

Figure 2. Activating $\mathrm{F} c \gamma$ receptor signaling. Fc $\gamma \mathrm{R}$ cross-linking by immunoglobulin (IgG) bound to antigen $(\mathrm{Ag})$, induces activation of Src family kinases and Syk family kinases in lipid rafts. These enzymes associate with phosphorylated tyrosines in the ITAM sequences. Syk then phosphorylates enzymes such as phosphatidylinositol 3-kinase (PI 3-K), phospholipase $\mathrm{C} \gamma$ (PLC $\gamma)$, and the adaptor molecules SLP76 (SH2-domain-containing leukocyte protein of $76 \mathrm{kDa}$ ) and LAT (linker for activation of T cells). PI 3-K produces phosphatidylinositol-3,4,5triphosphate $\left(\mathrm{PIP}_{3}\right)$, which leads to activation of Akt and extracellular signal-regulated kinase (ERK). PLC $\gamma$ produces inositoltrisphosphate $\left(\mathrm{IP}_{3}\right)$, and diacylglycerol (DAG). These second messengers cause calcium release from the endoplasmic reticulum (ER), and activation of protein kinase C (PKC), respectively. PKC leads to activation of ERK. Vav activates GTPases of the Rho and Rac family, which are involved in the regulation of the actin cytoskeleton. Other enzymes such as Bruton's tyrosine kinase (Btk) also activate the GTPase Rac to induce activation of nuclear factors such as JNK and NF- $\kappa \mathrm{B}$. P represents a phosphate group. $\mathrm{IP}_{3} \mathrm{R}$, receptor for $\mathrm{IP}_{3}$.

venting in this way the stimulation of key activating enzymes such as Akt, Btk, and PLC $\gamma$ (Figure 3B).

\subsection{Coexpression of Fc $\gamma$ Receptors and Threshold for Cell Activation}

As indicated above, different leukocytes express more than one activating Fc $\gamma \mathrm{R}$ (Table 1), and most of these cells also express at the same time the inhibitory Fc $\gamma$ RIIB. NK cells are particular leukocytes in this respect, because they only express Fc $\gamma$ RIIIA in humans and Fc $\gamma$ RIII in mice. The coexpression of both activating and inhibitory $\mathrm{F} c \gamma \mathrm{R}$ results in simultaneous triggering of activating and inhibitory signal transduction pathways (Figure 4A). Thus, a particular cell will respond when the sum of activating and inhibiting signals reach a threshold of activation that is determined by the relative expression of both types of $\mathrm{F} c \gamma \mathrm{R}$ (Figure 4B). The importance of the inhibitory Fc $\gamma$ RIIB in regulating many IgG-mediated responses in different leukocytes was made evident in Fc $\gamma$ RIIB-deficient mice, which showed enhanced activity of many IgG-mediated cell responses including: phagocytosis, immune complex-mediated inflammation, IgG-
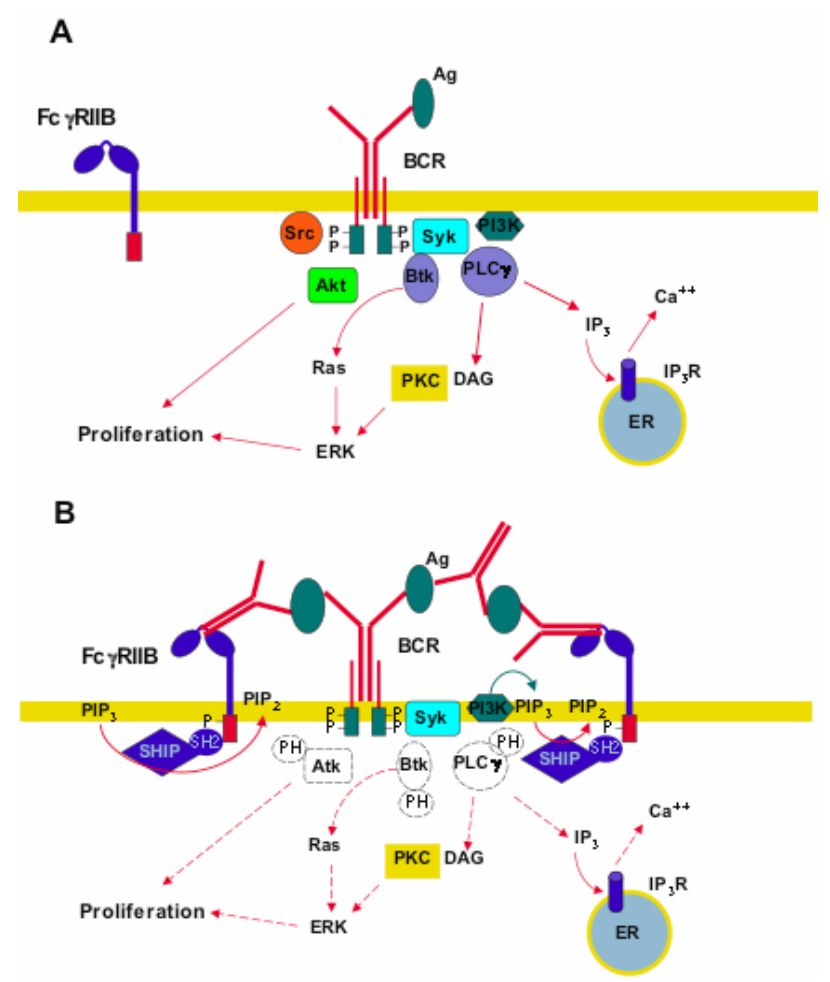

Figure 3. Inhibitory Fc $\gamma$ RIIB signaling. (A) Upon binding of antigen (Ag) to the B cell antigen receptor (BCR), Src family kinases and Syk family kinases get activated and become associated to the phosphorylated tyrosines in the ITAM sequences of the receptor. Syk then participates in activation of enzymes such as phosphatidylinositol 3-kinase (PI 3-K), Bruton's tyrosine kinase (Btk), and phospholipase C $\gamma$ (PLC $\gamma$ ). Btk leads to activation of Ras and extracellular signal-regulated kinase (ERK), which together with Akt induce cell proliferation. PLC $\gamma$ produces inositoltrisphosphate $\left(\mathrm{IP}_{3}\right)$, which causes calcium release, and diacylglycerol (DAG), which causes activation of protein kinase $\mathrm{C}$ (PKC). PKC also leads to cell proliferation via ERK; (B) After antigen recognition by both the inhibitory Fc $\gamma$ RIIB and the BCR, crosslinking of the receptors leads to phosphorylation of the ITIM sequence. Then, inositol 5-phosphatase (SHIP1) binds to the phosphorylated tyrosines within the ITIM via its SH-2 domain. SHIP1 transforms phosphatidylinositol-3,4,5-triphosphate $\left(\mathrm{PIP}_{3}\right)$ the main product of PI 3-K, into phosphatidylinositol-3,4-biphosphate $\left(\mathrm{PIP}_{2}\right)$; preventing in this way the stimulation of key activating enzymes (dashed lines). $\mathrm{P}$ represents a phosphate group. $\mathrm{IP}_{3} \mathrm{R}$, receptor for $\mathrm{IP}_{3}$. ER, endoplasmic reticulum.

mediated passive and active anaphylaxis, and IgE-mediated anaphylaxis $[42,43]$. They also showed enhanced dendritic cell maturation, and antigen presentation [44-46]. These results thus confirmed that Fc $\gamma$ RIIB regulates initiation of cell functions by generating, together with activating Fc $\gamma$ receptors, a threshold for cell activation [31, 47].

\subsection{Genetic Structure and Polymorphisms}

Analysis of Fc $\gamma \mathrm{R}$ genes in different species has identified 


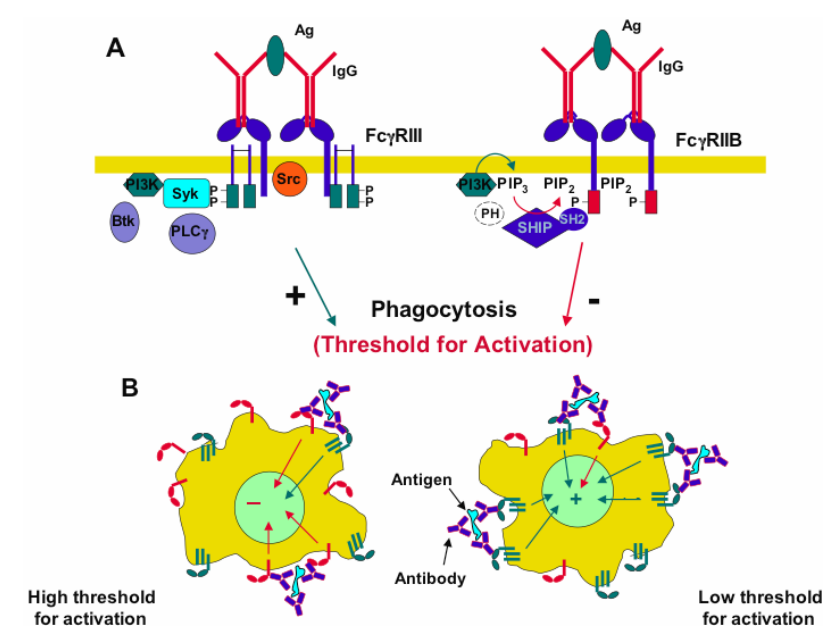

Figure 4. Threshold for activation. (A) The coexpression of both activating and inhibitory $\mathrm{Fc} \gamma$ receptors results in simultaneous triggering of activating and inhibitory signaling pathways, which will result in a threshold for activation of a specific cell response such as phagocytosis; (B) A particular cell will respond when the sum of signals from activating receptors (green), and inhibitory receptors (red) reach a threshold of activation that is determined by the relative expression of both types of $\mathrm{Fc} \gamma \mathrm{R}$.

orthologous receptors between mice and humans. The similarities come from gene localization and also from sequence homology of the extracellular portion of the receptors $[8,13]$. Therefore, the high affinity receptors Fc $\gamma$ RIA and FcRI, the low affinity receptors Fc $\gamma$ RIIA and Fc $\gamma$ RIII, and also the low affinity receptors Fc $\gamma$ RIIIA and Fc $\gamma$ RIV cluster in the same area of chromosome 1 (Figure 5). Similarly, the inhibitory Fc $\gamma$ RIIB gene maps to the same chromosome region, both in mice and humans (Figure 5). In addition, the human FcyRIIA and mouse Fc $\gamma$ RIII, as well as the human Fc $\gamma$ RIIIA and mouse Fc $\gamma$ RIV, present high sequence homology in their extracellular domains [13]. Despite this similarity, the receptors are not equivalent, since important differences have been detected between mice and human responses to IgG. For example, the human Fc $\gamma \mathrm{RI}$ binds the IgG1 and IgG3 subclasses with high affinity, while the mouse Fc $\gamma$ RI only binds IgG2a with high affinity (Table 1). In addition, the mouse FcyRIV is also able to bind IgE, while the human Fc $\gamma$ RIIIA is not $[48,49]$.

In addition, there are several polymorphisms in the human Fc $\gamma$ RII and Fc $\gamma$ RIII. For Fc $\gamma$ RIIA two allelic variants exist expressing either arginine or histidine at position 131 [50,51]. For Fc $\gamma$ RIIIA also allelic variants exist expressing either valine or phenylalanine at position 158 $[52,53]$. Similarly, for Fc $\gamma$ RIIIB on neutrophils, two isoforms exist, the NA1 and NA2 allotypes [54]. These isoforms differ by five nucleotides and four amino acids, with NA2 containing two additional N-linked glycosylation sites. These differences affect the capacity of Fc $\gamma$ RIIIB

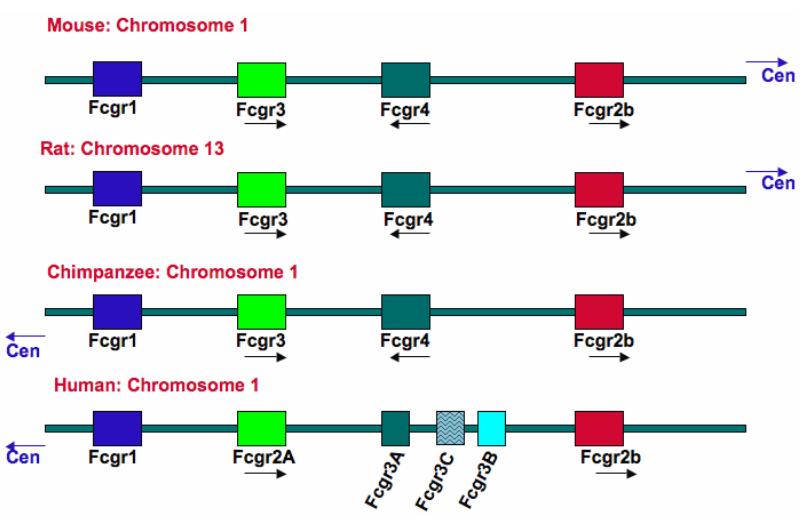

Figure 5. Genomic organization of the Fcy-receptor locus for various species. Figure modified from [13]. Data from the ensembl database (http://www.ensembl.org). Cen, centromer.

to interact with human IgG. Therefore, neutrophils from individuals who are homozygous for the NA1 allele have better phagocytosis of IgG-opsonized targets than do neutrophils from NA2-homozygous individuals [55,56]. These multiple $\mathrm{F} c \gamma \mathrm{R}$ and their allelic variants vary greatly in their affinity for different IgG classes [57]. Thus, a great interest exists to understand how different IgG molecules engage different $\mathrm{Fc} \gamma \mathrm{R}$ to activate the multiple cell responses associated with antibodies $\mathrm{Fc} \gamma$ receptor signaling.

\section{IgG-MEDIATED CELL FUNCTIONS}

\subsection{Fc $\gamma$ Receptor Affinity for IgG}

A single antibody molecule does not bind to $\mathrm{Fc} \gamma$ recaptors. However, antigen-antibody complexes promote many low affinity interactions between $\mathrm{F} \gamma \gamma \mathrm{R}$ on the surface of leukocytes and antibody complexes. The low affinity of antibodies for individual leukocyte $\mathrm{Fc} \gamma \mathrm{R}$ prevents recaptors from binding antibodies in the absence of antigen, thus reducing the chance of immune cell activation when there is not an infection. Immune complexes induce the crosslinking of $\mathrm{F} c \gamma \mathrm{R}$ to activate the many different antibody-mediated cell responses. Immune complexes are clearly of different kinds, since they are formed by different classes of antibodies, and in vivo studies have suggested that the different IgG classes have different activities. For example, IgG2b/c was better in eliminating B cells [58] and T cell lymphomas [59] than IgG1. Likewise, using class-switch variants of anti-erythrocyte antibodies it was found that $\operatorname{IgG} 2 \mathrm{a}$ and $\mathrm{IgG} 2 \mathrm{~b}$ were better in mediating phagocytosis of opsonized erythrocytes than IgG1 and IgG3 [60,61]. Also, polioencephalomyelitis induced by infection with lactate dehydrogenaseelevating virus (LDV) was delayed much better by $\operatorname{IgG2a}$ anti-LDV antibodies than any other IgG class of antiLDV antibodies [62]. In addition, the severity of glomerular inflammation was greater for $\operatorname{IgG} 2 \mathrm{a}$, followed by 
$\operatorname{IgG} 2 \mathrm{~b}$ and finally $\operatorname{IgG1}$ [63]. All these reports confirmed that different IgG classes mediate different cellular responses in vivo through $\mathrm{Fc} \gamma$ receptors.

Because, immune complexes of different kinds induce different cell responses, there has been a great interest in determining which type of $\operatorname{IgG}$ binds to which $\mathrm{Fc} \gamma \mathrm{R}$ and what particular receptor is involved in mediating the activity of particular IgG classes. Early studies showed that there is a high affinity receptor for $\operatorname{IgG}(\mathrm{Fc} \gamma \mathrm{RI})$, which binds preferably to IgG1 in humans and IgG2a in mice $[64,65]$. This receptor is saturated with serum $\operatorname{IgG}$ on leukocytes in the blood. As mentioned before, the other receptors have only low affinity and can bind to IgG only in the form of immune complexes (Table 1) [64,65]. In addition, it was clearly established that most $\mathrm{Fc} \gamma \mathrm{R}$ have a binding preference for IgG1 and IgG3 over the other classes of IgG (Table 1). Similarly, in mice it was found that IgG1 binds only to Fc $\gamma$ RIII, while IgG2a binds to all types of activating $\mathrm{Fc} \gamma \mathrm{R}$, and $\mathrm{IgG} 2 \mathrm{~b}$ binds to $\mathrm{Fc} \gamma \mathrm{RIII}$ and Fc $\gamma$ RIV. IgG3 does not seem to bind significantly to any of the Fc $\gamma$ R (Table 1) [29,61]. In agreement with these data, IgG1 activity was lost in mice deficient in Fc $\gamma$ RIII $[61,66]$. For IgG2a and IgG2b, however the correlation with particular $\mathrm{Fc} \gamma$ receptors is not as simple. In some model systems the activity of these IgG classes was lost in Fc $\gamma$ RIII-deficient mice, while it was not in others [13]. In a model of autoimmune hemolytic anemia, IgG2amediated response was highly dependent on Fc $\gamma$ RIII, but also Fc $\gamma$ RI and Fc $\gamma$ RIV contributed to the development of severe anemia [67]. In another model of arthritis, mice deficient in Fc $\gamma$ RI showed reduced cartilage destruction, and impaired protection from a bacterial infection, indicating the prominent role of $\mathrm{Fc} \gamma \mathrm{RI}$ in IgG2a-dependent immune functions [68]. Thus, IgG2a used all activating $\mathrm{Fc} \gamma$ receptors with important contribution from $\mathrm{Fc} \gamma \mathrm{RI}$ and FcyRIII. Similarly, for IgG2b a particular interaction with a particular $\mathrm{F} c y$ receptor cannot be clearly established. In models of IgG2b-dependent B cell depletion [69], and nephrotoxic nephritis [70], inhibition of Fc $\gamma$ RIV prevented $\mathrm{B}$ cell destruction and kidney inflammation, suggesting a central role for Fc $\gamma$ RIV in IgG2b-mediated functions. However, in models of IgG2b-dependent autoimmune hemolytic anemia [67], acute glomerular inflammation [63], or acute lung injury [71], Fc $\gamma$ RIV and also Fc $\gamma$ RIII were important for the activity of this IgG class. Thus, an order of activity is observed among the different IgG classes, and a preference of engagement with particular $\mathrm{Fc} \gamma$ receptors.

Part of the mechanism used to create this IgG-Fc $\gamma \mathrm{R}$ selectivity is revealed by studies that measured the affinities of IgG classes toward both activating Fc $\gamma$ recaptors and the inhibitory Fc $\gamma$ RIIB [13]. In this way, it was found that IgG1 has higher affinity for the inhibitory Fc $\gamma$ RIIB than for the activating Fc $\gamma$ RIII (Figure 6A), generating a high threshold for activation. In contrast, IgG2a and IgG2b have higher affinity for the activating Fc $\gamma$ RIV than for the inhibitory Fc $\gamma$ RIIB (Figure 6B), generating a lower threshold for activation. Thus, certain classes of $\operatorname{IgG}$, such as IgG1, are more dependent on the signaling from the inhibitory receptor. In agreement with this view, deletion of the inhibitory Fc $\gamma$ RIIB increased IgG1 activity in models of platelet depletion and tumor cell killing [61]. It is important to note that this model for IgG-Fc $\gamma \mathrm{R}$ selectivity is not static and can be modulated by other factors, such as the pattern of $F c \gamma R$ expression on the different leukocytes (Table 1), and cytokines that can modify $\mathrm{Fc} \gamma \mathrm{R}$ expression (Figure 7). Thus, Th1-type cytokines such as interferon- $\gamma$, and the anaphylatoxin C5a upregulate activating Fc $\gamma$ Rs expression and downregulate Fc $\gamma$ RIIB expression [72,73], whereas Th2-type cytokines, such as interleukin (IL)-4, IL-10, and transforming growth factor-beta (TGF- $\beta$ ) upregulate Fc $\gamma$ RIIB expression $[8,74]$.

\subsection{Each Fc $\gamma$ R Initiates Particular Signaling Pathways That Lead to Unique Cell Responses}

All the reports previously described have confirmed that different IgG classes mediate different cellular responses in vivo by engaging particular $\mathrm{Fc} \gamma$ receptors depending on the relative affinity of these receptors for a particular

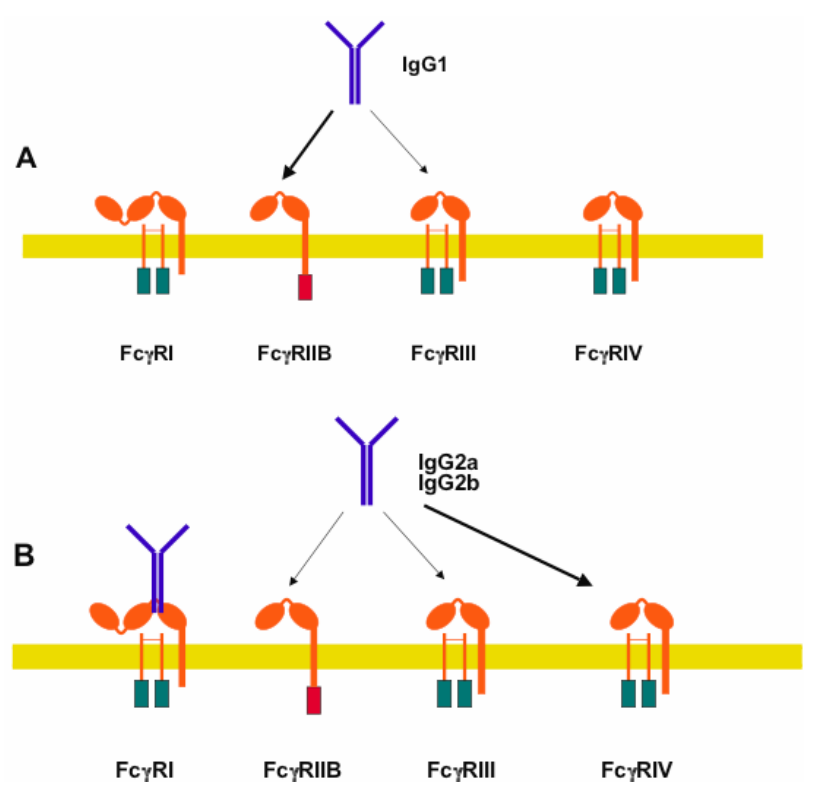

Figure 6. Relative preference of IgG classes for murine $\mathrm{Fc} \gamma$ receptors. (A) IgG1 has higher affinity for the inhibitory Fc $\gamma$ RIIB (thick arrow) than for the activating Fc $\gamma$ RIII (thin arrow); (B) In contrast, IgG2a and IgG2b have higher affinity for the activating Fc $\gamma$ RIV (thick arrow) than for the inhibitory Fc $\gamma$ RIIB (thin arrow). Thus, certain classes of $\mathrm{IgG}$, such as IgG1, are more dependent on signaling from the inhibitory receptor. 


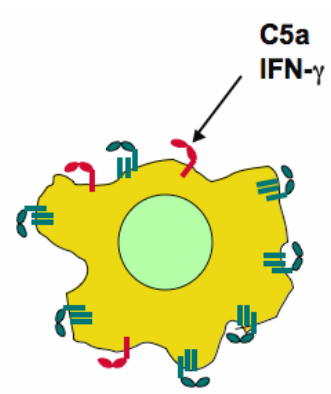

Downregulate Fc $\gamma$ RIIB Upregulate activating $\mathrm{Fc} \gamma \mathrm{Rs}$

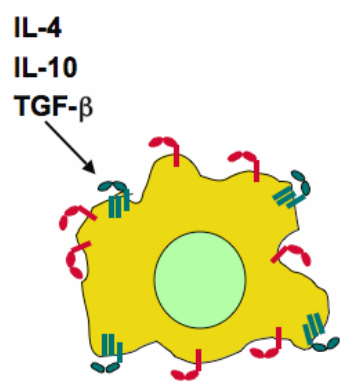

Upregulate Fc $\gamma$ RIIE
Figure 7. Cytokines can modify Fc $\gamma \mathrm{R}$ expression. Th1-type cytokines such as interferon- $\gamma$ IFN- $\gamma$, and the anaphylatoxin C5a upregulate activating $\mathrm{Fc} \gamma \mathrm{R}$ (green) expression and downregulate Fc $\gamma$ RIIB (red) expression, whereas Th2-type cytokines, such as interleukin (IL)-4, IL-10, and transforming growth factor-beta (TGF- $\beta$ ) upregulate Fc $\gamma$ RIIB expression.

IgG class. However, these findings do not explain what cell response is activated in response to a particular type of $\mathrm{Fc} \gamma$ receptor. One possibility is that each leukocyte is already programmed to respond in a certain way when immune complexes crosslink its Fc $\gamma$ receptors. Another possibility is that each $\mathrm{Fc} \gamma \mathrm{R}$ signals differently to initiate a particular cell response. The first possibility is not very likely because a particular leukocyte can respond with various cell functions, and also because the same class of $\mathrm{IgG}$ induces different responses in different leukocytes. The idea that each $\mathrm{Fc} \gamma \mathrm{R}$ is able to initiate a particular cell response is supported by recent reports where individual Fc $\gamma \mathrm{R}$ were crosslinked on human neutrophils. As described above, human neutrophils express only two $\mathrm{Fc} \gamma \mathrm{R}$, Fc $\gamma$ RIIA and Fc $\gamma$ RIIIB [28]. These receptors are different in the way they are anchored to the cell membrane. Fc $\gamma$ RIIA has a typical transmembrane and cytoplasmic tail containing an ITAM for signaling. In contrast, Fc $\gamma$ RIIIB is a GPI-linked receptor, lacking a cytoplasmic tail, and its signaling mechanism remains unidentified. However, early reports indicated that both $\mathrm{Fc} \gamma \mathrm{R}$ are capable of signaling and inducing particular responses [75]. More recently, it was found that FcrRIIA, but not Fc $\gamma$ RIIIB could induce an increase in L-selectin expression [76]. Opposite to this, Fc $\gamma$ RIIIB, but not Fc $\gamma$ RIIA, was able to activate $\beta 1$ integrins [77]. In addition, when the major cell response of neutrophils, arguably phagocytosis, was examined, Fc $\gamma$ RIIA was the predominant $\mathrm{F} c \gamma \mathrm{R}$ mediating this response. Fc $\gamma$ RIIIB contribution to phagocytosis was minimal [78]. In complete contrast, Fc $\gamma$ RIIIB signaling to the neutrophil nucleus was much more efficient than Fc $\gamma$ RIIA signaling. Fc $\gamma$ RIIIB, but not Fc $\gamma$ RIIA, promoted a robust increase in phosphorylated ERK in the nucleus, and also efficient phosphorylation of the nuclear factor Elk-1 [79]. Interestingly, the Fc $\gamma$ RIIA signaling pathway resembles the classical ITAM-mediated pathway (Figure 2) [5], while Fc $\gamma$ RIIIB signaling pathway remains a mystery (Figure 8). Taken together, these reports strongly support the hypothesis that each $\mathrm{F} c \gamma \mathrm{R}$ is capable of initiating particular signaling pathways that lead to unique cell responses.

\section{EFFECT OF ANTIBODY GLYCOSYLATION ON FC RECEPTOR FUNCTION}

All antibodies are glycoproteins with various carbohydrate side chains attached to the protein backbone. The immunoglobulin classes $\operatorname{IgM}, \operatorname{IgA}$, and $\operatorname{IgE}$ have several exposed carbohydrate side chains. In contrast, IgG molecules have one carbohydrate side chain. This carbohydrate (sugar) side chain is important for IgG function. Deletion of the sugar side chain results in an altered conformation of the antibody molecule and in deficient binding to $\mathrm{Fc} \gamma$ receptors [80]. This carbohydrate domain is heterogeneous in its sugar composition. More than 30 different glycosylation variants of $\operatorname{IgG}$ can be found in serum of a healthy human or mouse individuals [14]. This heterogeneity is formed by variable addition of sugar residues such as sialic acid, $\mathrm{N}$-acetylglucosamine, galactose and fucose in straight or branching patterns. Although heterogeneous, the pattern of glycosylation seems to change in various physiological conditions. For example, terminal galactose and sialic acid residues were reduced in active autoimmune disease [18,81], while they were increased during pregnancy $[82,83]$. It is not clear what these changes in the glycosylation pattern

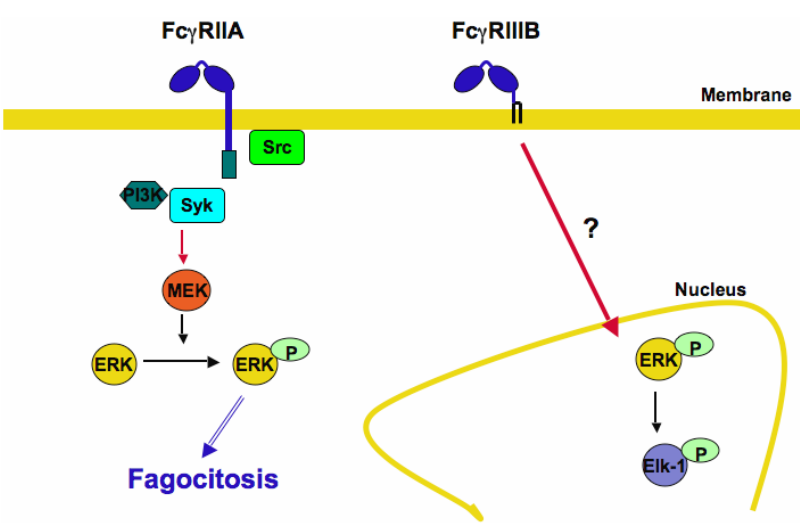

Figure 8. Each $F c \gamma R$ initiates particular signaling pathways leading to unique cell responses. In human neutrophils, Fc $\gamma$ RIIA activates the classical ITAM-mediated signaling pathway leading to efficient phagocytosis. In contrast, Fc $\gamma$ RIIIB promotes a robust increase in phosphorylated ERK in the nucleus, and also efficient phosphorylation of the nuclear factor Elk-1. The Fc $\gamma$ RIIIB signaling pathway remains a mystery. P represents a phosphate group; Syk, spleen tyrosine kinase; PI 3-K, phosphatidylinositol 3-kinase; MEK, ERK kinase; ERK, extracellular signal-regulated kinase. 
represent, but it seems that they can modulate IgG activity [84]. In contrast, IgG antibodies with reduced fucose residues presented higher affinity for human FcR $\gamma$ IIIA and its mouse ortholog Fc $\gamma$ RIV and showed improved antibody-dependent cellular toxicity against various tumor cells $[61,85,86]$. IgG antibodies with high levels of terminal sialic acid presented lower affinity for Fc $\gamma$ receptors and also reduced inflammatory activity $[18,87$, 88]. In addition, IgG antibodies with abundant sialic can bind to other cellular receptors different from Fc receptors. SIGNR-1 (specific ICAM-3 grabbing nonintegrin related 1) and its human ortholog DC-SIGN (dendritic cell specific ICAM-3 grabbing nonintegrin) were identified as receptors for sialic acid rich IgG [87]. Moreover, this subpopulation of antibodies was also suggested to be responsible for the anti-inflammatory activity of intravenous Ig (IVIg) therapy, because in SIGNR-1 knockout mice, IVIg did not show an anti-inflammatory effect in a model of rheumatoid arthritis [87]. IVIg therapy that consists on administration of high doses of pooled serum $\mathrm{IgG}$ from many different donors has been used for many years to treat various autoimmune diseases such as rheumatoid arthritis and thrombocytopenia [19]. In addition, it has been reported that IVIg therapy can change the threshold for activation of cells by upregulation of the inhibitory Fc $\gamma$ RIIB and downregulation of activating $\mathrm{F} c \gamma \mathrm{R}$ in some mouse models and in patients with chronic inflammatory demyelinating polyneuropathy $[70,89,90]$. Thus, glycosylation patterns are critical for binding to particular Fc $\gamma$ receptors and other novel antibody receptors. These reports underline the need of further studies on antibody-Fc receptor interactions to better understand the multiple effects of antibody molecules.

\section{NEW LIGANDS FOR Fc $\gamma$ RECEPTORS}

Antibodies are the bona fide ligands for Fc receptors. However, some recent reports have identified other molecules different from IgG that can bind Fc $\gamma$ receptors and can also activate the cell functions characteristic of antibodies. Two members of the pentraxin superfamily [91], which are multimeric cyclic proteins, are reported to bind human and mouse Fc $\gamma$ receptors. These pentraxins are C-reactive protein (CRP) and serum amyloid P (SAP) [92-95]. These proteins are usually not found in serum of healthy individuals, but they are rapidly expressed in large amounts during inflammation and microbial infections. CRP and SAP are capable of binding to several microorganisms including bacteria and fungi and thus targeting them for phagocytosis by neutrophils and macrophages $[92,96]$. These reports suggest that these pentraxin proteins behave like antibodies recognizing foreign antigens on pathogens and directing them to cells of the innate immune system [16]. In support of this idea, it was also found that $\mathrm{Fc} \gamma$ receptor uptake of CRP-opsonized
Streptococcus pneumoniae increased the immune response against these bacteria [95]. Moreover, CRP also seems to have an anti-inflammatory effect mediated by Fc $\gamma$ receptors. In Fc $\gamma \mathrm{R}$-deficient mice, administration of CRP did not protect from nephrotoxic nephritis or immune thrombocytopenia $[94,97]$.

\section{CONCLUSION}

Fc Receptors expressed in a wide variety of leukocytes are capable of activating in response to various antibodies different cellular responses of great importance for host defense and for immune regulation. The different subclasses of $\operatorname{IgG}$ antibodies are recognized by Fc $\gamma$ receptors with different affinities. Also singular Fc $\gamma$ receptors seem to activate particular cell responses. This provides two ways for modulating cellular responses. In addition, expression of both activating and inhibitory Fc $\gamma$ receptors establishes a threshold for activation of innate immune cells. Thus, Fc $\gamma$ receptors are responsible of controlling the intensity of the immune response and of preventing unnecessary activation of innate immune cells, which might damage normal tissues. Novel glycosylation variants of $\mathrm{IgG}$ that bind $\mathrm{Fc} \gamma$ receptors with different affinities have been identified and also the anti-inflamematory activity of intravenous IgG therapy. Finally, novel receptors for antibody variants and novel Fc $\gamma$ receptor ligands are been recognized. These new information together with new studies on $\mathrm{IgG}-\mathrm{Fc} \gamma$ receptor interactions will certainly help us to develop new ways of controlling not only antibody-mediated effector functions directed against pathogens and tumors, but also the exaggerated antibody-mediated cell responses associated with auto-immunity.

\section{ACKNOWLEDGEMENTS}

Research in the authors' laboratory is supported by grant 168098 from Consejo Nacional de Ciencia y Tecnología, Mexico, and by grants IB200811, IA202013-2 (to EUQ), and IN205311-2 (to CR) from Dirección General de Asuntos del Personal Académico, Universidad Nacional Autónoma de México, Mexico

\section{REFERENCES}

[1] Akira, S., Uematsu, S. and Takeuchi, O. (2006) Pathogen recognition and innate immunity. Cell, 124, 783-801. doi:10.1016/j.cell.2006.02.015

[2] Kawai, T. and Akira, S. (2011) Toll-like receptors and their crosstalk with other innate receptors in infection and immunity. Immunity, 34, 637-650. doi:10.1016/j.immuni.2011.05.006

[3] Iwasaki, A. and Medzhitov, R. (2010) Regulation of adaptive immunity by the innate immune system. Science, 327, 291-295. doi:10.1126/science. 1183021

[4] Ballow, M. (2002) Primary immunodeficiency disorders: 
Antibody deficiency. Journal of Allergy and Clinical Immunology, 109, 581-591. doi:10.1067/mai.2002.122466

[5] Rosales, C. (2007) Fc receptor and integrin signaling in phagocytes. Signal Transduction, 7, 386-401. doi:10.1002/sita.200700141

[6] Tohyama, Y. and Yamamura, H. (2006) Complement-mediated phagocytosis-The role of Syk. IUBMB Life, 58, 304-308. doi:10.1080/15216540600746377

[7] Heyman, B. (2000) Regulation of antibody responses via antibodies, complement, and Fc receptors. Annual Review of Immunology, 18, 709-737.

doi:10.1146/annurev.immunol.18.1.709

[8] Nimmerjahn, F. and Ravetch, J. (2008) Fc $\gamma$ receptors as regulators of immune responses. Nature Reviews Immunology, 8, 34-47. doi:10.1038/nri2206

[9] Powell, M.S. and Hogarth, P.M. (2008) Fc receptors. Advances in Experimental Medicine and Biology, 640, 2234. doi:10.1007/978-0-387-09789-3_3

[10] García-García, E. and Rosales, C. (2009) Fc receptor signaling in leukocytes: Role in host defense and immune regulation. Current Immunology Reviews, 5, 227-242. doi:10.2174/157339509788921229

[11] Hogarth, P. (2002) Fc receptors are major mediators of antibody based inflammation in autoimmunity. Current Opinion in Immunology, 14, 798-802. doi:10.1016/S0952-7915(02)00409-0

[12] Takai, T. (2002) Roles of Fc receptors in autoimmunity. Nature Reviews Immunology, 2, 580-592.

[13] Nimmerjahn, F. and Ravetch, J. (2006) Fc $\gamma$ receptors: Old friends and new family members. Immunity, 24, 19-28. doi:10.1016/i.immuni.2005.11.010

[14] Arnold, J., Wormald, M., Sim, R., Rudd, P. and Dwek, R. (2007) The impact of glycosylation on the biological function and structure of human immunoglobulins. Annual Review of Immunology, 25, 21-50. doi:10.1146/annurev.immunol.25.022106.141702

[15] Jinghua, L., Lorraine, L.M., Kristopher, D.M., Carolyn, M., Terry, W.D.C. and Peter, D.S. (2008) Structural recognition and functional activation of $\mathrm{Fc} \gamma \mathrm{R}$ by innate pentraxins. Nature, 456, 989-992. doi: $10.1038 /$ nature 07468

[16] Marnell, L., Mold, C. and Du Clos, T. (2005) C-reactive protein: Ligands, receptors and role in inflammation. Clinical Immunology, 117, 104-111. doi:10.1016/j.clim.2005.08.004

[17] Anthony, R., Nimmerjahn, F., Ashline, D., Reinhold, V., Paulson, J. and Ravetch, J. (2008) Recapitulation of IVIG anti-inflammatory activity with a recombinant IgG Fc. Science, 320, 373-376. doi:10.1126/science.1154315

[18] Kaneko, Y., Nimmerjahn, F. and Ravetch, J. (2006) Antiinflammatory activity of immunoglobulin $\mathrm{G}$ resulting from Fc sialylation. Science, 313, 670-673. doi:10.1126/science.1129594

[19] Nimmerjahn, F. and Ravetch, J. (2008) Anti-inflammatory actions of intravenous immunoglobulin. Annual Review of Immunology, 26, 513-533. doi:10.1146/annurev.immunol.26.021607.090232
[20] Jones, S.L., Lindberg, F.P. and Brown, E.J. (1999) Phagocytosis. In: Paul, W.E., Ed., Fundamental Immunology, Lippincott-Raven Publishers, Philadelphia, 997-1020.

[21] Sánchez-Mejorada, G. and Rosales, C. (1998) Signal transduction by immunoglobulin Fc receptors. Journal of Leukocyte Biology, 63, 521-533.

[22] Ravetch, J.V. and Bolland, S. (2001) IgG Fc receptors. Annual Review of Immunology, 19, 275-290. doi:10.1146/annurev.immunol.19.1.275

[23] Ravetch, J.V. (2003) Fc receptors. In: Paul, W.E., Ed., Fundamental Immunology, Lippincott Williams \& Wilkins, Philadelphia, 631-684.

[24] Fodor, S., Jakus, Z. and Mócsai, A. (2006) ITAM-based signaling beyond the adaptive immune response. Immunology Letters, 104, 29-37. doi:10.1016/j.imlet.2005.11.001

[25] Underhill, D.M. and Goodridge, H.S. (2007) The many faces of ITAMs. Trends in Immunology, 28, 66-73. doi:10.1016/j.it.2006.12.004

[26] Tridandapani, S., Siefker, K., Teillaud, J.-L., Carter, J.E., Wewers, M.D. and Anderson, C.L. (2002) Regulated expression and inhibitory function of $\mathrm{Fc} \gamma \mathrm{RIIb}$ in human monocytic cells. The Journal of Biological Chemistry, 277, 5082-5089. doi:10.1074/jbc.M110277200

[27] Daëron, M. and Lesourne, R. (2006) Negative signaling in Fc receptor complexes. Advances in Immunology, 89, 39-86. doi:10.1016/S0065-2776(05)89002-9

[28] Willcocks, L.C., Smith, K.G. and Clatworthy, M.R. (2009) Low-affinity $\mathrm{Fc} \gamma$ receptors, autoimmunity and infection. Expert Reviews in Molecular Medicine, 11, e24. doi:10.1017/S1462399409001161

[29] Nimmerjahn, F., Bruhns, P., Horiuchi, K. and Ravetch, J. (2005) Fc $\gamma$ RIV: A novel FcR with distinct IgG subclass specificity. Immunity, 23, 41-51. doi:10.1016/j.immuni.2005.05.010

[30] Stefanescu, R.N., Olferiev, M., Liu, Y. and Pricop, L. (2004) Inhibitory Fc gamma receptors: From gene to disease. Journal of Clinical Immunology, 24, 315-326. doi:10.1023/B:JOCI.0000029105.47772.04

[31] Boruchov, A., Heller, G., Veri, M., Bonvini, E., Ravetch, J. and Young, J. (2005) Activating and inhibitory IgG Fc receptors on human DCs mediate opposing functions. The Journal of Clinical Investigation, 115, 2914-2923. doi:10.1172/JCI24772

[32] Anderson, C. and Grey, H. (1974) Receptors for aggregated IgG on mouse lymphocytes: Their presence on thymocytes, thymus-derived, and bone marrow-derived lymphocytes. The Journal of Experimental Medicine, 139, 1175-1188. doi:10.1084/jem.139.5.1175

[33] Leclerc, J., Plater, C. and Fridman, W. (1977) The role of the $\mathrm{Fc}$ receptor $(\mathrm{FcR})$ of thymus-derived lymphocytes. I. Presence of FcR on cytotoxic lymphocytes and absence of direct role in cytotoxicity. European Journal of Immunology, 7, 543-548.doi:10.1002/eji.1830070810

[34] Stout, R.D. and Herzenberg, L.A. (1975) The Fc receptor on thymus-derived lymphocytes. I. detection of a subpopulation of murine $\mathrm{T}$ lymphocytes bearing the $\mathrm{Fc}$ re- 
ceptor. The Journal of Experimental Medicine, 142, 611621. doi:10.1084/jem.142.3.611

[35] Rajendran, L. and Simons, K. (2005) Lipid rafts and membrane dynamics. Journal of Cell Science, 118, 1099-1102. doi: $10.1242 /$ jes. 01681

[36] Bezman, N. and Koretzky, G.A. (2007) Compartamentalization of ITAM and integrin signaling by adapter molecules. Immunology Review, 218, 9-28. doi:10.1111/j.1600-065X.2007.00541.x

[37] Newbrough, S.A., Mocsai, A., Clemens, R.A., Wu, J.N., Silverman, M.A., Singer, A.L., Lowell, C.A. and Koretzky, G.A. (2003) SLP-76 regulates Fc $\gamma$ receptor and integrin signaling in neutrophils. Immunity, 19, 761-769. doi:10.1016/S1074-7613(03)00305-4

[38] Myung, P.S., Clements, J.L., White, D.W., Malik, Z.A., Cowdery, J.S., Allen, L.-A.H., Harty, J.T., Kusner, D.J. and Koretzky, G.A. (2000) In vitro and in vivo macrophage function can occur independently of SLP-76. International Immunology, 12, 887-897. doi:10.1093/intimm/12.6.887

[39] Nichols, K.E., Haines, K., Myung, P.S., Newbrough, S., Myers, E., Jumaa, H., Shedlock, D.J., Shen, H. and Koretzky, G.A. (2004) Macrophage activation and Fc $\gamma$ receptor-mediated signaling do not require expression of the SLP-76 and SLP-65 adaptors. Journal of Leukocyte Biology, 75, 541-552. doi:10.1189/jlb.0703312

[40] Tridandapani, S., Lyden, T.W., Smith, J.L., Carter, J.E., Coggeshall, K.M. and Anderson, C.L. (2000) The adapter protein LAT enhances Fc $\gamma$ Receptor-mediated signal transduction in myeloid cells. The Journal of Biological Chemistry, 275, 20480-20487. doi:10.1074/jbc.M909462199

[41] Daëron, M., Latour, S., Malbec, O., Espinosa, E., Pina, P., Pasmans, S. and Fridman, W.H. (1995) The same tyrosine-based inhibition motif, in the intracytoplasmic domain of Fc $\gamma$ RIIB, regulates negatively BCR-, TCR-, and FcR-dependent cell activation. Immunity, 3, 635-646. doi:10.1016/1074-7613(95)90134-5

[42] Bolland, S. and Ravetch, J. (2000) Spontaneous autoimmune disease in Fc $\gamma$ RIIB-deficient mice results from strain-specific epistasis. Immunity, 13, 277-285. doi:10.1016/S1074-7613(00)00027-3

[43] Takai, T., Ono, M., Hikida, M., Ohmori, H. and Ravetch, J. (1996) Augmented humoral and anaphylactic responses in Fc gamma RII-deficient mice. Nature, 379, 346-349. doi:10.1038/379346a0

[44] Dhodapkar, K., Banerjee, D., Connolly, J., Kukreja, A., Matayeva, E., Veri, M., Ravetch, J., Steinman, R. and Dhodapkar, M. (2007) Selective blockade of the inhibitory $\mathrm{Fc} \gamma$ receptor $(\mathrm{Fc} \gamma \mathrm{RIIB})$ in human dendritic cells and monocytes induces a type I interferon response program. The Journal of Experimental Medicine, 204, 1359-1369. doi:10.1084/jem.20062545

[45] Dhodapkar, K., Kaufman, J., Ehlers, M., Banerjee, D., Bonvini, E., Koenig, S., Steinman, R., Ravetch, J. and Dhodapkar, M. (2005) Selective blockade of inhibitory Fcgamma receptor enables human dendritic cell maturation with IL-12p70 production and immunity to antibody-coated tumor cells. Proceedings of the National
Academy of Sciences of the United States of America, 102, 2910-2915. doi:10.1073/pnas.0500014102

[46] Kalergis, A. and Ravetch, J. (2002) Inducing tumor immunity through the selective engagement of activating Fc gamma receptors on dendritic cells. The Journal of Experimental Medicine, 195, 1653-1659. doi:10.1084/jem.20020338

[47] Nimmerjahn, F. and Ravetch, J.V. (2010) Antibody-mediated modulation of immune responses. Immunology Review, 236, 265-275. doi:10.1111/j.1600-065X.2010.00910.x

[48] Hirano, M., Davis, R.S., Fine, W.D., Nakamura, S., Shimizu, K.Y., H., kato, K., Stephan, R.P. and Cooper, M.D. (2007) IgEb immune complexes activate macrophages through Fe $\gamma$ RIV binding. Nature Immunology, 8, 762-771. doi:10.1038/ni1477

[49] Mancardi, D., Iannascoli, B., Hoos, S., England, P., Daëron, M. and Bruhns, P. (2008) Fc $\gamma$ RIV is a mouse IgE receptor that resembles macrophage FceRI in humans and promotes IgE-induced lung inflammation. The Journal of Clinical Investigation, 118, 3738-3750. doi:10.1172/JCI36452

[50] Salmon, J.E., Edberg, J.C., Brogle, N.L. and Kimberly, R.P. (1992) Allelic polimorphisms of human Fc $\gamma$ receptor IIA and Fc $\gamma$ receptor IIIB. Independent mechanisms for differences in human phagocyte function. The Journal of Clinical Investigation, 89, 1274-1281. doi:10.1172/JCI115712

[51] Tax, W.J.M., Willems, H.W., Reekers, P.P.M., Capel, P.J.A. and Koene, R.A.P. (1983) Polymorphism in mitogenic effect of IgG1 monoclonal antibodies against T3 antigen on human T cells. Nature, 304, 445-447. doi: $10.1038 / 304445 \mathrm{a} 0$

[52] Koene, H.R., Kleijer, M., Swaak, A.J.G., Sullivan, K.E., Bijl, M., Petri, M.A., Kallenberg, C.G.M., Roos, D., von dem Borne, A.E.G.K. and de Haas, M. (1998) The Fc $\gamma$ RIIIA-158F allele is a risk factor for systemic lupus erythematosus. Arthritis \& Rheumatism, 41, 1813-1818. doi:10.1002/1529-0131(199810)41:10<1813::AID-ART1 3>3.0.CO;2-6

[53] Wu, J., Edberg, J.C., Redecha, P.B., Bansal, V., Guyre, P.M., Coleman, K., Salmon, J.E. and Kimberly, R.P. (1997) A novel polymorphism of Fc $\gamma$ RIIIa (CD16) alters receptor function and predisposes to autoimmune disease. The Journal of Clinical Investigation, 100, 1059-1070. doi:10.1172/JCI119616

[54] Huizinga, T.W.J., Kleijer, M., Tetteroo, P.A.T., Roos, D. and von dem Borne, A.E.G.K. (1990) Biallelic neutrophil $\mathrm{Na}$-antigen system is associated with a polymorphism on the phospho-inositol-linked $\mathrm{Fc} \gamma$ receptor III (CD16). Blood, 75, 213-217.

[55] Hatta, Y., Tsuchiya, N., Ohashi, J., Matsushita, M., Fujiwara, K., Hagiwara, K., Juji, T. and Tokunaga, K. (1999) Association of $\mathrm{Fc}$ gamma receptor IIIB, but not of $\mathrm{Fc}$ gamma receptor IIA and IIIA, polymorphisms with systemic lupus erythematosus in Japanese. Genes \& Immunity, 1, 53-60. doi:10.1038/sj.gene.6363639

[56] Salmon, J.E., Edberg, J.C. and Kimberly, R.P. (1990) Fc $\gamma$ receptor III on human neutrophils. Allelic variants have 
functionally distinct capacities. The Journal of Clinical Investigation, 85, 1287-1295. doi:10.1172/JCI114566

[57] Bruhns, P., Iannascoli, B., England, P., Mancardi, D., Fernandez, N., Jorieux, S. and Daëron, M. (2009) Specificity and affinity of human $\mathrm{Fc} \gamma$ receptors and their polymorphic variants for human IgG subclasses. Blood, 113, 3716-3725. doi:10.1182/blood-2008-09-179754

[58] Uchida, J., Hamaguchi, Y., Oliver, J., Ravetch, J., Poe, J., Haas, K. and Tedder, T. (2004) The innate mononuclear phagocyte network depletes B lymphocytes through Fc receptor-dependent mechanisms during anti-CD20 antibody immunotherapy. The Journal of Experimental Medicine, 199, 1659-1669. doi:10.1084/jem.20040119

[59] Lambert, S., Okada, C. and Levy, R. (2004) TCR vaccines against a murine $\mathrm{T}$ cell lymphoma: a primary role for antibodies of the IgG2c class in tumor protection. The Journal of Immunology, 172, 929-936.

[60] Fossati-Jimack, L., Ioan-Facsinay, A., Reininger, L., Chicheportiche, Y., Watanabe, N., Saito, T., Hofhuis, F.M., Gessner, J.E., Schiller, C., Schmidt, R.E., Honjo, T., Verbeek, J.S. and Izui, S. (2000) Markedly different pathogenicity of four immunoglobulin $\mathrm{G}$ isotype-switch variants of an anti-erythrocyte autoantibody is based on their capacity to interact in vivo with the low-affinity $\mathrm{Fc} \gamma$ receptor III. The Journal of Experimental Medicine, 191, 1293-1302. doi:10.1084/jem.191.8.1293

[61] Nimmerjahn, F. and Ravetch, J. (2005) Divergent immunoglobulin $G$ subclass activity through selective Fc receptor binding. Science, 310, 1510-1512.

doi: $10.1126 /$ science. 1118948

[62] Markine-Goriaynoff, D. and Coutelier, J. (2002) Increased efficacy of the immunoglobulin G2a subclass in antibody-mediated protection against lactate dehydrogenase-elevating virus-induced polioencephalomyelitis revealed with switch mutants. Journal of Virology, 76, 432435. doi:10.1128/JVI.76.1.432-435.2002

[63] Giorgini, A., Brown, H.J., Lock, H.R., Nimmerjahn, F., Ravetch, J.V., Verbeek, J.S., Sacks, S.H. and Robson, M.G. (2008) Fc $\gamma$ RIII and Fc $\gamma$ RIV are indispensable for acute glomerular inflammation induced by switch variant monoclonal antibodies. The Journal of Immunology, 181, 8745-8752.

[64] Daëron, M. (1997) Fc receptor biology. Annual Review of Immunology, 15, 203-234. doi:10.1146/annurev.immunol.15.1.203

[65] Ravetch, J.V. and Kinet, J.P. (1991) Fc receptors. Annual Review of Immunology, 9, 457-492. doi:10.1146/annurev.iy.09.040191.002325

[66] Meyer, D., Schiller, C., Westermann, J., Izui, S., Hazenbos, W., Verbeek, J., Schmidt, R. and Gessner, J. (1998) Fc $\gamma$ RIII (CD16)-deficient mice show IgG isotype-dependent protection to experimental autoimmune hemolytic anemia. Blood, 92, 3997-4002.

[67] Baudino, L., Nimmerjahn, F., Azeredo da Silveira, S., Martinez-Soria, E., Saito, T., Carroll, M., Ravetch, J., Verbeek, J. and Izui, S. (2008) Differential contribution of three activating IgG Fc receptors (Fc $\gamma$ RI, Fc $\gamma$ RIII, and Fc $\gamma$ RIV) to IgG2a- and IgG2b-induced autoimmune hemolytic anemia in mice. The Journal of Immunology, 118,

\section{8-1953.}

[68] Ioan-Facsinay, A., de Kimpe, S., Hellwig, S., van Lent, P., Hofhuis, F., van Ojik, H., Sedlik, C., da Silveira, S., Gerber, J., de Jong, Y., Roozendaal, R., Aarden, L., van den Berg, W., Saito, T., Mosser, D., Amigorena, S., Izui, S., van Ommen, G., van Vugt, M., van de Winkel, J. and Verbeek, J. (2002) Fc $\gamma$ RI (CD64) contributes substantially to severity of arthritis, hypersensitivity responses, and protection from bacterial infection. Immunity, 16, 391402. doi:10.1016/S1074-7613(02)00294-7

[69] Hamaguchi, Y., Xiu, Y., Komura, K., Nimmerjahn, F. and Tedder, T.F. (2006) Antibody isotype-specific engagement of $\mathrm{Fc} \gamma$ receptors regulate B lymphocyte depletion during CD20 immunotherapy. The Journal of Experimental Medicine, 203, 743-753. doi:10.1084/jem.20052283

[70] Kaneko, Y., Nimmerjahn, F., Madaio, M. and Ravetch, J. (2006) Pathology and protection in nephrotoxic nephritis is determined by selective engagement of specific Fc receptors. The Journal of Experimental Medicine, 203, 789797. doi:10.1084/jem.20051900

[71] Syed, S., Konrad, S., Wiege, K., Nieswandt, B., Nimmerjahn, F., Schmidt, R. and Gessner, J. (2009) Both Fc $\gamma$ RIV and Fc $\gamma$ RIII are essential receptors mediating type II and type III autoimmune responses via FcR $\gamma$-LATdependent generation of C5a. European Journal of Immunology, 39, 3343-3356. doi:10.1002/eji.200939884

[72] Pricop, L., Redecha, P., Teillaud, J.-L., Frey, J., Fridman, W.H., Sautès-Fridman, C. and Salmon, J.E. (2001) Differential modulation of stimulatory and inhibitory $\mathrm{Fc} \gamma$ receptors on human monocytes by Th1 and Th2 cytokines. The Journal of Immunology, 166, 531-537.

[73] Schmidt, R. and Gessner, J. (2005) Fc receptors and their interaction with complement in autoimmunity. Immunology Letters, 100, 56-67. doi:10.1016/j.imlet.2005.06.022

[74] Tridandapani, S., Wardrop, R., Baran, C.P., Wang, Y., Opalek, J.M., Caligiuri, M.A. and Marsh, C.B. (2003) TGF- $\beta 1$ suppresses myeloid $\mathrm{Fc} \gamma$ receptor function by regulating the expression and function of the common $\gamma$-subunit. The Journal of Immunology, 170, 4572-4577.

[75] Salmon, J.E., Browle, N.L., Edberg, J.C. and Kimberly, R.P. (1991) Fc $\gamma$ receptor III induces actin polymerization in human neutrophils and primes phagocytosis mediated by Fc $\gamma$ receptor II. The Journal of Immunology, 146, 997-1004.

[76] Kocher, M., Siegel, M.E., Edberg, J.C. and Kimberly, R.P. (1997) Cross-linking of Fc $\gamma$ receptor IIa and Fc $\gamma$ receptor IIIb induces different proadhesive phenotypes on human neutrophils. The Journal of Immunology, 159, 3940-3948.

[77] Ortiz-Stern, A. and Rosales, C. (2005) Fc $\gamma$ RIIIB stimulation promotes $\beta 1$ integrin activation in human neutrophils. Journal of Leukocyte Biology, 77, 787-799. doi:10.1189/jlb.0504310

[78] Rivas-Fuentes, S., García-García, E., Nieto-Castañeda, G. and Rosales, C. (2010) Fc $\gamma$ receptors exhibit different phagocytosis potential in human neutrophils. Cellular Immunology, 263, 114-121. 
doi:10.1016/j.cellimm.2010.03.006

[79] García-García, E., Nieto-Castañeda, G., Ruiz-Saldaña, M., Mora, N. and Rosales, C. (2009) Fc $\gamma$ RIIA and Fc $\gamma$ RIIIB mediate nuclear factor activation through separate signaling pathways in human neutrophils. The Journal of Immunology, 182, 4547-4556. doi:10.4049/jimmunol.0801468

[80] Shields, R., Namenuk, A., Hong, K., Meng, Y., Rae, J., Briggs, J., Xie, D., Lai, J., Stadlen, A., Li, B., Fox, J. and Presta, L. (2001) High resolution mapping of the binding site on human IgG1 for Fc $\gamma$ RI, Fc $\gamma$ RII, Fc $\gamma$ RIII, and FcRn and design of IgG1 variants with improved binding to the Fc $\gamma$ R. The Journal of Biological Chemistry, 276, 65916604. doi:10.1074/jbc.M009483200

[81] Mizuochi, T., Hamako, J., Nose, M. and Titani, K. (1990) Structural changes in the oligosaccharide chains of IgG in autoimmune MRL/Mp-lpr/lpr mice. The Journal of Immunology, 145, 1794-1798.

[82] Rook, G., Steele, J., Brealey, R., Whyte, A., Isenberg, D., Sumar, N., Nelson, J., Bodman, K., Young, A. and Roitt, I. (1991) Changes in IgG glycoform levels are associated with remission of arthritis during pregnancy. Journal of Autoimmunity, 4, 779-794. doi:10.1016/0896-8411(91)90173-A

[83] van de Geijn, F., Wuhrer, M., Selman, M., Willemsen, S., de Man, Y., Deelder, A., Hazes, J. and Dolhain, R. (2009) Immunoglobulin $\mathrm{G}$ galactosylation and sialylation are associated with pregnancy-induced improvement of rheumatoid arthritis and the postpartum flare: results from a large prospective cohort study. Arthritis Research \& Therapy, 11, R193. doi:10.1186/ar2892

[84] Jefferis, R. (2009) Glycosylation as a strategy to improve antibody-based therapeutics. Nature Reviews Drug Discovery, 8, 226-234. doi:10.1038/nrd2804

[85] Shinkawa, T., Nakamura, K., Yamane, N., Shoji-Hosaka, E., Kanda, Y., Sakurada, M., Uchida, K., Anazawa, H., Satoh, M., Yamasaki, M., Hanai, N. and Shitara, K. (2003) The absence of fucose but not the presence of galactose or bisecting $\mathrm{N}$-acetylglucosamine of human IgG1 complex-type oligosaccharides shows the critical role of enhancing antibody-dependent cellular cytotoxicity. The Journal of Biological Chemistry, 278, 3466-3473. doi:10.1074/jbc.M210665200

[86] Shields, R., Lai, J., Keck, R., O’Connell, L., Hong, K., Meng, Y., Weikert, S. and Presta, L. (2002) Lack of fucose on human IgG1 N-linked oligosaccharide improves binding to human Fc $\gamma$ RIII and antibody-dependent cellular toxicity. The Journal of Biological Chemistry, 277, 26733-26740. doi:10.1074/jbc.M202069200

[87] Anthony, R., Wermeling, F., Karlsson, M. and Ravetch, J. (2008) Identification of a receptor required for the anti-inflammatory activity of IVIG. Proceedings of the
National Academy of Sciences of the United States of America, 105, 19571-19578.

doi:10.1073/pnas.0810163105

[88] Scallon, B., Tam, S., McCarthy, S., Cai, A. and Raju, T. (2007) Higher levels of sialylated Fc glycans in immunoglobulin $\mathrm{G}$ molecules can adversely impact functionality. Molecular Immunology, 44, 1524-1532. doi:10.1016/j.molimm.2006.09.005

[89] Bruhns, P., Samuelsson, A., Pollard, J. and Ravetch, J. (2003) Colony-stimulating factor-1-dependent macrophages are responsible for IVIG protection in antibody-induced autoimmune disease. Immunity, 18, 573-581. doi:10.1016/S1074-7613(03)00080-3

[90] Tackenberg, B., Jelcic, I., Baerenwaldt, A., Oertel, W.H., Sommer, N., Nimmerjahn, F. and Lunemann, J.D. (2009) Impaired inhibitory Fc $\gamma$ RIIB expression on B cells in chronic inflammatory demyelinating polyneuropathy. Proceedings of the National Academy of Sciences of the United States of America, 106, 4788-4792. doi:10.1073/pnas.0807319106

[91] Agrawal, A., Singh, P., Bottazzi, B., Garlanda, C. and Mantovani, A. (2009) Pattern recognition by pentraxins. Advances in Experimental Medicine and Biology, 653, 98116. doi:10.1007/978-1-4419-0901-5 7

[92] Bharadwaj, D., Mold, C., Markham, E. and Du Clos, T. (2001) Serum amyloid P component binds to Fc gamma receptors and opsonizes particles for phagocytosis. The Journal of Immunology, 166, 6735-6741.

[93] Lu, J., Marnell, L., Marjon, K., Mold, C., Du Clos, T. and Sun, P. (2008) Structural recognition and functional activation of $\mathrm{Fc} \gamma \mathrm{R}$ by innate pentraxins. Nature, 456, 989992. doi: $10.1038 /$ nature 07468

[94] Marjon, K., Marnell, L., Mold, C. and Du Clos, T. (2009) Macrophages activated by $\mathrm{C}$-reactive protein through $\mathrm{Fc} \gamma$ RI transfer suppression of immune thrombocytopenia. The Journal of Immunology, 182, 1397-1403.

[95] Thomas-Rudolph, D., Du Clos, T., Snapper, C. and Mold, C. (2007) C-reactive protein enhances immunity to Streptococcus pneumoniae by targeting uptake to Fc $\gamma \mathrm{R}$ on dendritic cells. The Journal of Immunology, 178, 7283-7291.

[96] Bharadwaj, D., Stein, M., Volzer, M., Mold, C. and Du Clos, T. (1999) The major receptor for C-reactive protein on leukocytes is Fc gamma receptor II. The Journal of Experimental Medicine, 190, 585-590. doi:10.1084/jem.190.4.585

[97] Rodriguez, W., Mold, C., Kataranovski, M., Hutt, J., Marnell, L., Verbeek, J. and Du Clos, T. (2007) C-reactive protein-mediated suppression of nephrotoxic nephritis: Role of macrophages, complement, and Fc $\gamma$ receptors. The Journal of Immunology, 178, 530-538. 